\title{
Safety and efficacy of blood exchange transfusion for priapism complicating sickle cell disease.
}

Samir K. Ballas

Thomas Jefferson University

David Lyon

Thomas Jefferson University; Chinook Regional Hospital

Follow this and additional works at: https://jdc.jefferson.edu/cardeza_foundation

Part of the Hematology Commons

Let us know how access to this document benefits you

\section{Recommended Citation}

Ballas, Samir K. and Lyon, David, "Safety and efficacy of blood exchange transfusion for priapism complicating sickle cell disease." (2016). Cardeza Foundation for Hematologic Research. Paper 38.

https://jdc.jefferson.edu/cardeza_foundation/38

This Article is brought to you for free and open access by the Jefferson Digital Commons. The Jefferson Digital Commons is a service of Thomas Jefferson University's Center for Teaching and Learning (CTL). The Commons is a showcase for Jefferson books and journals, peer-reviewed scholarly publications, unique historical collections from the University archives, and teaching tools. The Jefferson Digital Commons allows researchers and interested readers anywhere in the world to learn about and keep up to date with Jefferson scholarship. This article has been accepted for inclusion in Cardeza Foundation for Hematologic Research by an authorized administrator of the Jefferson Digital Commons. For more information, please contact: JeffersonDigitalCommons@jefferson.edu. 


\title{
Safety and Efficacy of Blood Exchange Transfusion for Priapism Complicating Sickle Cell Disease
}

\author{
Samir K. Ballas and *David Lyon \\ Cardeza Foundation for Hematologic Research, Department of Medicine, Jefferson Medical \\ College, Thomas Jefferson University, Philadelphia, PA, USA \\ *Current address: Chinook Regional Hospital Lethbridge, Albert T1J 1W5 Canada
}

Correspondence:

Samir K. Ballas MD FACP

Cardeza Foundation

1020 Locust Street

Philadelphia, PA 19107

Email: samir.ballas@jefferson.edu

Phone: 856-745-6380

Fax: 856-795-0809

Text word count: 2271

Abstract word count: 235

Number of pages: 12

Number of Tables: 4

Number of Figures: 1

Number of references: 25

Key Words: Impotence, Shunt Surgery, Neurological Complications, Safety

Short Title: Safety of Exchange Transfusion for Priapism

Supported in part by the Sickle Cell Program of the Department of Health of the Commonwealth of Pennsylvania for the Philadelphia Region 


\begin{abstract}
Background. Priapism is unwanted painful penile erection that affects about $36 \%$ of boys and men with sickle cell disease most of whom have sickle cell anemia. Clinically, priapism could be stuttering, minor or major. The first two types are mild, last $<4$ hours, are usually treated at home, have good prognosis with normal sexual function. The major type of priapism lasts $>4 \mathrm{~h}$, associated with severe pain, requires hospitalization; often does not respond to medical treatment and may require shunt surgery. Untreated major priapism and surgical intervention often cause impotence. In this study we report our 15 year experience in treating adult patients with sickle cell disease and major priapism with blood exchange transfusion after being refractory to other medical therapies. Methods. Adult male African Americans patients with sickle cell disease and major priapism were enrolled in this study and followed for 15 years. A Haemonitics V-50 machine was initially used for whole blood exchange and was later replaced with Cobe Spectra machine for RBC exchange. Results. We used 239 blood exchanges requiring 1,136 RBC units. We maintained a post-exchange hemoglobin level of about $10 \mathrm{~g} / \mathrm{dL}$ and hemoglobin $\mathrm{S}$ level < $30 \%$. None of the patients had any neurological complications such as headache, seizures, neurological deficits or obtundation post-exchange. Conclusion. Together, the data indicate that blood exchange transfusion for the treatment of patients with sickle cell disease and major priapism is efficacious and safe.
\end{abstract}




\section{Introduction}

Priapism is unwanted and sustained painful erection lasting 4 or more hours. It is a common complication of sickle cell disease (SCD) affecting $89 \%$ of males with at least one episode of priapism by the time they are 20 years-old [1]. It is most common in patients with SS, who account for approximately $80 \%$ to $90 \%$ of reported cases [2-5]. However, it does occur in all forms of SCD including $\mathrm{Hb}$ SC disease, sickle thalassemia, and in sickle trait $[2,6]$.

Clinically, priapism may be stuttering, minor, or major. Stuttering priapism is the occurrence of short, repetitive, and reversible painful episodes with detumescence occurring within $<4$ hours after the onset of erection. This pattern has a good prognosis and is associated with normal sexual function and rarely requires medical intervention. The prevalence of stuttering priapism varies from approximately $2 \%$ up to $60 \%$ of men and boys with SCD according to different reports $[5,7,8]$. Minor priapism is isolated and infrequent episodes of painful erection that last < 4 hours and do not require medical intervention. Major priapism, however, is a prolonged episode of painful erection lasting longer than 4 hours and that often requires hospitalization, with medical and/or surgical intervention, Partial or total impotence is often associated with major episodes of priapism.

Anatomically, priapism may be bicorporal or tricorporal. Magnetic resonance imaging of the penis can differentiate these two patterns. Bicorporal priapism involves both corpora cavernosa and is common in children with stuttering pattern. This pattern has a good prognosis and is associated with normal sexual function. Tricorporal priapism involves both corpora cavernosa and the corpus spongiosum and is more common in older patients. It is a painful erection that 
may last several days or weeks and may be followed by complete or partial impotence. Its prevalence varies between 6.5\% [5] and 38\% [7] of men with SCD. Management of priapism is highly controversial. Controlled studies are lacking, therapeutic approaches are controversial and often conflicting, and medical and surgical therapies fail in most patients. The major goals of treatment include pain relief and prevention of impotence. Stuttering and minor episodes of priapism usually last less than 4 hours and are often treated at home with analgesics, benzodiazepines, or pseudoephedrine and do not require treatment at the ED or hospital. Management of major priapism include, among other things, penile aspiration, irrigation with epinephrine, hydroxyurea, hormonal therapy, bicalutamide, hydralazine, sildenafil, oxygen, hyperhydration, exchange transfusion and shunt surgery with variable and inconsistent results [9-14]. Moreover, case reports of 7 children [13, 14] described acute neurological events following exchange transfusion for priapism thus limiting enthusiasm for further trials of this therapy. The purpose of this study is to describe the safety and efficacy of 239 blood exchange transfusions that were performed between 1985 and 2009 for 10 patients with SCD and recurrent major episodes of priapism.

\section{Materials and Methods}

Patients. The ten patients enrolled in this study were adult male African Americans who had major priapism not responsive to standard medical treatment that included analgesics, benzodiazepines, penile aspiration and penile irrigation with epinephrine. They were followed up from January 1985 through June 2009.. Two of the patients had blood exchange for other complications of SCD in addition to major priapism as described in Results. The Sickle Cell 
center was supported by the Sickle Cell Program of the Department of Health of the Commonwealth of Pennsylvania for the Philadelphia Region. Written consent was obtained from the patients for enrollment in the program. The Department of Health required the submission of quarterly reports describing the activities of our center. These included, among other things, the number of admissions to the Emergency department, admissions to the hospital, clinic visits, types of SCD, complications and management. The program and its various activities were approved by the IRB. Some of lab data in this study, however, were obtained retrospectively from the patients' records.

Lab Data. Hematological data were obtained by routine methods, SCD types were initially determined by solubility testing, hemoglobin electrophoresis in alkaline and acidic media, Thin layer isoelectric focusing or by high-performance liquid chromatography (HPLC) and later followed by gel electrophoresis. Hemoglobin F determination was by the alkaline denaturation method [15] or by HPLC. Alpha genotypes and $\beta^{\mathrm{S}}$ haplotypes were determined as described previously $[16,17]$.

Priapism. All the ten patients described had major priapism that lasted longer than 4 hours and failed to responded to various measures before initiating blood exchange transfusion. These measures included penile aspiration, irrigation with epinephrine, opioid analgesia and to preventative measures with hydration, analgesics, benzodiazepines, pseudoephedrine, hydralazine, sildenafil and hydroxyurea. As will be mentioned below, some patients had recurrent attacks of major priapism that required preventative blood exchange transfusion every 4-8 months or sooner if needed. 
Blood Exchange Transfusion. In the 1980's a Haemonitics V-50 machine was used for whole blood exchange. Aliquots of whole blood were drawn intermittently at 50-70 $\mathrm{mL} / \mathrm{min}$. After $500 \mathrm{~mL}$ were removed an equal volume of reconstituted donor red cells plus $5 \%$ albumin and saline were transfused. This was repeated several times until all the red cell concentrates were transfused [12]. More exchanges were sometimes used to bring the $\%$ of $\mathrm{Hb} \mathrm{S}<30 \%$. In the 1990's a Cobe Spectra machine replaced the Haemonetics V-50 and was used for RBC exchanges. A patient's height, weight and desired end hematocrit (Hct) were programmed into Spectra's computer to determine the exact red cell volume needed. If a patient's Hct was $<27 \%$, the exchange was programed to have an end Hct of $27 \%$. If a patient;s Hct was between 27 and $36 \%$, the machine was programmed to keep the end Hct at the same pre-exchange level. No patient's Hct had to be reduced below the pre-exchange level unless the patient received simple transfusion(s) prior to exchange. The patient's whole blood was drawn and the red cells separated off and discarded. The patient's plasma was returned with donor RBC. Red cell exchange protocol has been described previously [18]. For both types of exchange, sickle negative donor RBC were phenotyped for $\mathrm{ABO}, \mathrm{D}, \mathrm{c}, \mathrm{C}, \mathrm{e}, \mathrm{E}$ and Kell antigens. The aim of each exchange was to bring or keep the patient's $\mathrm{Hb}$ level about $10 \mathrm{~g} \%$ and reduce $\mathrm{Hb} \mathrm{S}$ to $\leq 30 \%$. A low $\mathrm{Hb} / \mathrm{Hct}$ in SS reduces blood viscocity and is protective [19]. When peripheral access was possible, two-arm procedures were used and the draw side was always an anti-cubital vein. On the return side, the contralateral antecubital was preferred, but a smaller vein would also suffice but sometomes reducing the exchange rate, When peripheral access was impossible, a dual port, large bore catheter (e.g. Shiley) was placed surgically. 
Statistical analysis. The paired t test was used to compare the pre- and post-exchange transfusion lab data.

\section{Results}

All exchange procedures were not accompanied by any significant morbidity or complications during the years of follow-up. Table 1 summarizes pertinent epidemiological data and RBC replacements for each patient. Ages of the patients at presentation with priapism were between

21 and 46 years and ages when last seen were between 26 and 53. All patients were followed-up in our sickle cell center after blood exchange as part of their longitudinal plans of management. .This allowed us to determine the presence of any possible immediate and delayed side effects of the blood exchange procedures. Patients 1 and 4 had sickle- $\beta^{0}$-thalassemia and patient 8 had $\mathrm{Hb}$ SO Arab. Patient 2 had blood exchange transfusions both for priapism and for prevention of stroke with 27 of the 82 exchanges for priapism and the remaining 55 for stroke prevention. Similarly, patient 9 had blood exchanges for priapism and for end stage renal disease and iron overload with 3 of the 50 exchanges for priapism and the remaining 47 for end stage renal disease and iron overload. None of the patients had two $\alpha$-gene deletions. Most patients were carriers of the Benin $\beta^{\mathrm{S}}$ haplotype followed by the Central African Republic (CAR) haplotype. Patient 2 presented with unusually brisk reticulocytosis requiring more units of $\mathrm{RBC}$ to reduce $\mathrm{Hb} \mathrm{S}<30 \%$. Patient 8 presented late, after 24 hours of onset of priapism. All other patients presented within less than 24 hours of onset of priapism. A total of 239 blood exchanges were performed on all patients requiring 1,136 units of RBCs.

Table 2 shows the individual total and mean hematological parameters before and after blood exchange. In all cases the post-exchange parameters were significantly different from the pre- 
exchange parameters. The post-exchange $\mathrm{Hb} \mathrm{S}$ was significantly less than the pre-exchange values $(\mathrm{p}<0.001)$. The post-exchange $\mathrm{Hb} / \mathrm{Hct}$ values were significantly higher than the preexchange numbers. The reasons for this were, as described in Materials and Methods, that the machine was calibrated to keep the end Hct at $27 \%$ or to match the pre-exchange value in case it is $>27 \%$.

Table 3 lists the clinical outcomes of priapism after the exchange procedures. Priapism resolved in the majority of the patients. Failure to respond to blood exchange transfusion occurred in two patients (patients 5 and 8) who required shunt surgery and penile implant due to impotence. Two patients (patient 1 and 2) required blood exchange on a chronic basis.

\section{Discussion.}

The most important aspect of this study is the safety and efficacy of blood exchange transfusion for the treatment of major episodes of priapism due to SCD. None of the patients had two $\alpha$-gene deletions, a situation similar to the lack of two $\alpha$-gene deletions in patients with SCD and stroke [20]. The genotype/phenotype relationship is an important aspect of sickle cell disease. The CAR haplotype, for example, is known to be associated with severe SCD. In the patients described in this study there seems to be an association of the Benin haplotype with priapism. The number of the patients studied, however, is too small to make reliable conclusions and more studied are needed to clarify the genotype/phenotype relationships in SCD. None of the patients described experienced serious side effects. Patient 10 had genitofemoral neuralgia characterized by pain and burning sensation in the perineum and the adjacent area of the scrotum. This condition is a common cause of pelvic and low abdominal pain in the general population $[21,22]$. To the best of our knowledge, however, this has not been described in patients with SCD or, most likely; it 
could have been considered as a manifestation of sickle cell pain. Pathophysiologically, the swelling of the penis and the adjacent area of the perineum could have exerted pressure on the genital branch of the genitofemoral nerve that passes with the spermatic cord to the cremasteric muscles with sensory innervation to the bottom of the scrotum. In women this genital branch innervates the lower part of the uterus and the labia majora. This neuropathic pain in this patient resolved gradually over 2-3 months.

An association between blood exchange transfusion for priapism due to SCD and severe neurologic events including severe headache, seizures, focal neurological deficits and obtundation has been made [13,14]. This association has been named the ASPEN syndrome (Association of Sickle cell disease, Priapism, Exchange transfusion and Neurologic events). All seven patients described were children ages 7 to 13 years. Imaging studies (computed tomography, MRI or cerebral arteriography) in 5 of the 6 patients described by Rackoff et al. [13] demonstrated vascular abnormalities, including irregularity, stenosis, and complete occlusion of vessels. The patient described by Siegel et al. [14] had normal cerebral computed tomography but MRI and cerebral arteriography were not done. Moreover, the post-exchange $\mathrm{Hb}$ levels in these patients were dangerously too high for patients with SS as shown in Table 4 and Figure 1, In addition the post-exchange $\mathrm{Hb}$ values of our patients were significantly lower than those in the children with the so called ASPEN syndrome (Table 4). Most notably, the Hb level of the patient described by Siegel et al. (Table 4) increased by over 100\% indicating sudden expansion of the blood volume and the associated increase in whole blood viscosity. Thus it is the post-exchange whole blood viscosity together with the cerebral vessel abnormalities that are the real cause of the ASPEN syndrome and not the exchange procedure in itself. The situation is similar to the fatal outcome of an adult patient with SS who was hyper-transfused rapidly to a $\mathrm{Hb}$ 
level over $10 \mathrm{~g} / \mathrm{dL}$ [23]. It is important to note that although the Hct is the major determinant of whole blood viscosity, plasma components also are important contributors to whole blood viscosity. Thus in SCD the inflammatory meditators in plasma and the increased levels of fibrinogen, other coagulation factors and immunoglobulins worsen whole blood viscosity. This dual cause of blood viscosity was reported in a patient with SS and acute chest syndromes (ACS) where blood exchange transfusion was not effective in resolving the ACS despite the reduction of $\mathrm{Hb} \mathrm{S}$ to $<30 \%$ [24]. Plasmapheresis following blood exchange transfusion in this patient was effective in resolving the ACS [24].

In summary, our study demonstrates the safety and efficacy of blood exchange transfusion for patients with major priapism due to SCD provided the procedure is calibrated to keep the postexchange $\mathrm{Hb}$ level about $10 \mathrm{~g} / \mathrm{dL}$ thus avoiding the induction of iatrogenic whole blood hyperviscosity and its serious sequelae. Future controlled trials using blood exchange transfusion to abort acute major priapism and the use of $\mathrm{HU}$ as a preventative major are needed. Moreover, the multi-center study of HU in SS (MSH) considered recurrent major priapism an acute painful crisis that meets the criteria for inclusion in the study [25]. Thus controlled trials to treat recurrent major priapism with HU vs standard medical treatment with or without blood exchange transfusion are needed.

\section{References}

1. Expert Panel Report. Evidence-Based Management of Sickle Cell Disease. In: US Department of Health and Human Services, ed. Bethesda, MD: National Institutes of Health, National Heart, Lung and Blood Institute; 2014.

2. Adeyoju AB, Olujohungbe AB, Morris J, Yardumian A, Bareford D, Akenova A, Akinyanju O, Cinkotai K, O'Reilly PH. Priapism in sickle-cell disease; incidence, risk factors and complications an international multicentre study. BJU Int. 2002;90(9):898-902. [PMID: 12460353] 
3. Powars DR, Johnson CS. Priapism. Hematol Oncol Clin North Am. 1996;10(6):1363-72. [PMID: 8956023]

4. Rogers ZR. Priapism in sickle cell disease. Hematol Oncol Clin North Am. 2005;19(5):917-28, viii. [PMID: 16214652]

5. Sharpsteen JR, Jr., Powars D, Johnson C, Rogers ZR, Williams WD, Posch RJ. Multisystem damage associated with tricorporal priapism in sickle cell disease. Am J Med. 1993;94(3):289-95. [PMID: 8452153]

6. Okpala I, Westerdale N, Jegede T, Cheung B. Etilefrine for the prevention of priapism in adult sickle cell disease. Br J Haematol. 2002;118(3):918-21. [PMID: 12181066]

7. Emond AM, Holman R, Hayes RJ, Serjeant GR. Priapism and impotence in homozygous sickle cell disease. Arch Intern Med. 1980;140(11):1434-7. [PMID: 6159833]

8. Serjeant GR, de Ceulaer K, Maude GH. Stilboestrol and stuttering priapism in homozygous sicklecell disease. Lancet. 1985;2(8467):1274-6. [PMID: 2866338]

9. Mantadakis E, Ewalt DH, Cavender JD, Rogers ZR, Buchanan GR. Outpatient penile aspiration and epinephrine irrigation for young patients with sickle cell anemia and prolonged priapism. Blood. 2000;95(1):78-82. [PMID: 10607688]

10. Baron M, Leiter E. The management of priapism in sickle cell anemia. J Urol. 1978;119(5):610-1. [PMID: 660730]

11. Seeler RA. Intensive transfusion therapy for priapism in boys with sickle cell anemia. J Urol. 1973;110(3):360-3. [PMID: 4725748]

12. Talacki CA, Ballas SK. Modified method of exchange transfusion in sickle cell disease. J Clin Apher. 1990;5(4):183-7. [PMID: 2228996]

13. Rackoff WR, Ohene-Frempong K, Month S, Scott JP, Neahring B, Cohen AR. Neurologic events after partial exchange transfusion for priapism in sickle cell disease. J Pediatr. 1992;120(6):8825. [PMID: 1593347]

14. Siegel JF, Rich MA, Brock WA. Association of sickle cell disease, priapism, exchange transfusion and neurological events: ASPEN syndrome. J Urol. 1993;150(5 Pt 1):1480-2. [PMID: 8411432]

15. Betke K, Marti HR, Schlicht I. Estimation of small percentages of foetal haemoglobin. Nature. 1959;184(Suppl 24):1877-8. [PMID: 13800165]

16. Steiner RM, Ballas SK, Castro O, Pomerantz K, Embury S, Kutlar A, Burchott S, Bagasra O. Retroviral burden and disease outcome in HIV-I infected patients with sickle cell anemia (SS) (Abstract \#305). Paper presented at: National Sickle Cell Disease Conference, 1997. Washington DC.

17. Ballas SK, Cai SP, Gabuzda T, Chehab FF. Molecular basis of asymptomatic beta-thalassemia major in an African American individual. Am J Med Genet. 1997;69(2):196-9. [PMID: 9056561]

18. Janes SL, Pocock M, Bishop E, Bevan DH. Automated red cell exchange in sickle cell disease. Br J Haematol. 1997;97(2):256-8. [PMID: 9163584]

19. Eckman JR. Techniques for blood administration in sickle cell patients. Semin Hematol. 2001;38(1 Suppl 1):23-9. [PMID: 11206958]

20. Ballas SK. Effect of alpha-globin genotype on the pathophysiology of sickle cell disease. Pediatr Pathol Mol Med. 2001;20(2):107-21]

21. Harms BA, DeHaas DR, Jr., Starling JR. Diagnosis and management of genitofemoral neuralgia. Arch Surg. 1984;119(3):339-41. [PMID: 6696629]

22. Teixeira MJ, Aun R, de Oliveira Junior JO, Segushi HH, de Almeida GM. Genitofemoral neuralgia. Rev Hosp Clin Fac Med Sao Paulo. 1982;37(5):236-40. [PMID: 6984976]

23. Serjeant G. Blood transfusion in sickle cell disease: a cautionary tale. Lancet. 2003;361(9369):1659-60. [PMID: 12747923] 
24. Ayache S, Herman JH, Hall N, Kent T, Ballas SK. Plasma exchange may benefit acute chest syndrome in sickle cell disease. J Clin Apheresis. 2007;22(2):82-3. [PMID: Not available]

25. Charache S, Terrin ML, Moore RD, Dover GJ, Barton FB, Eckert SV, McMahon RP, Bonds DR. Effect of hydroxyurea on the frequency of painful crises in sickle cell anemia. Investigators of the Multicenter Study of Hydroxyurea in Sickle Cell Anemia. N Engl J Med. 1995;332(20):1317-22. [PMID: 7715639]

\section{Legend to Figure}

The Effect of hematocrit on whole blood viscosity. Hematocrit $>30 \%$ in sickle cell disease increases whole blood viscosity significantly compared to normal. From Ballas SK. Sickle Cell Pain, $2^{\text {nd }}$ Ed. IASP Washington, DC 2014

Table I. Characteristics of the Patients with Priapism who Required Red Blood Cell Exchange

\begin{tabular}{|c|c|c|c|c|c|c|c|}
\hline Patient \# & $\begin{array}{l}\text { Age at First } \\
\text { RBC } \\
\text { Exchange }\end{array}$ & $\begin{array}{l}\text { Age Last } \\
\text { Seen }\end{array}$ & Diagnosis & $\begin{array}{l}\alpha- \\
\text { Genotype }\end{array}$ & $\beta^{\mathrm{S}}$-Haplotype & $\begin{array}{l}\text { \# of } \\
\text { Exchanges }\end{array}$ & $\begin{array}{l}\text { Total RBC } \\
\text { Exchanged }\end{array}$ \\
\hline 1 & 38 & 53 & S- $\boldsymbol{\beta}^{0}$-Thal & $-\alpha / \alpha \alpha$ & Sen, Atypical & 58 & 282 \\
\hline 2 & 21 & 30 & SS & $\alpha \boldsymbol{\alpha} / \alpha \alpha$ & Ben, Atypical & $82^{*}$ & $528^{*}$ \\
\hline 3 & 28 & 29 & SS & $\alpha \alpha / \alpha \alpha$ & Ben, Ben & 1 & 3 \\
\hline 4 & 21 & 26 & 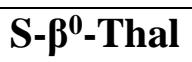 & $\alpha \boldsymbol{\alpha} / \boldsymbol{\alpha \alpha}$ & Sen, Atypical & 19 & 76 \\
\hline 5 & 32 & 40 & SS & $\alpha \boldsymbol{\alpha} / \boldsymbol{\alpha \alpha}$ & Ben, CAR & 19 & 64 \\
\hline 6 & 25 & 45 & SS & $\alpha \boldsymbol{\alpha} / \boldsymbol{\alpha \alpha}$ & Ben, Ben & 5 & 44 \\
\hline 7 & 27 & 27 & SS & $\alpha \alpha / \alpha \alpha$ & Ben, CAR & 3 & 16 \\
\hline 8 & 46 & 57 & $\begin{array}{l}\text { Hb SO } \\
\text { Arab }\end{array}$ & $\alpha \alpha / \alpha \alpha$ & Sen, Atypical & 1 & 8 \\
\hline 9 & 23 & 28 & SS & $\boldsymbol{\alpha \alpha} / \boldsymbol{\alpha \alpha}$ & Ben, CAR & $\mathbf{5 0}^{\dagger}$ & $105^{\dagger}$ \\
\hline 10 & 26 & 30 & SS & $-\alpha / \alpha \alpha$ & Ben, CAR & 1 & 10 \\
\hline & & & & & Total & $239^{* *}$ & $1,136^{* *}$ \\
\hline
\end{tabular}

Ben = Benin; CAR = Central African Republic; RBC = Red blood cell; Sen = Senegal; SS = Sickle cell anemia; $S$-Thal $=$ Sickle thalassemia

* 27 of the 82 blood exchanges and 157 of the RBC exchanged were for priapism and the remaining 55 exchanges and $371 \mathrm{RBC}$ exchanged were for stroke prevention.

$\uparrow 3$ of the 50 exchanges and 21 of the RBC exchanged were for priapism and the remaining 47 exchanges and $84 \mathrm{RBC}$ exchanged were for end stage renal disease and iron overload.

** 137 of the 239 blood exchanges and 681 of the RBC exchanged were for priapism and the remaining 102 exchanges and $455 \mathrm{RBC}$ exchanged were for other indications as mentioned above. 
Table II. Hematological Parameters of the Patients Studied Before and After Red Blood Cell Exchange

\begin{tabular}{|l|l|l|l|l|l|l|}
\hline \multirow{2}{*}{ Patient \# } & \multicolumn{2}{l}{ Hb g/dl* ${ }^{*}$ Hct \%* } & \multicolumn{2}{l|}{$\%$ Hb S* } \\
\cline { 2 - 7 } & Pre-Exchange & Post-Exchange & Pre-Exchange & Post-Exchange & Pre-Exchange & Post-Exchange \\
\hline 1 & $(28) 9.8 \pm 1.0$ & $(25) 10.6 \pm 1.1$ & $(25) 29.7 \pm 3.4$ & $(28) 31.5 \pm 3.6$ & $\begin{array}{l}(25) 72.1 \pm \\
18.1\end{array}$ & $(26) 36.8 \pm 8.6$ \\
\hline 2 & & & & & \\
& $(71) 7.7 \pm 1.0$ & $(69) 9.2 \pm 1.1$ & $(71) 23.0 \pm 3.1$ & $(70) 27.0 \pm 3.2$ & $(55) 48.0 \pm$ \\
15.6 & $(55) 21.9 \pm 14.3$ \\
\hline 3 & 5.1 & & & & 86.1 & 43.4 \\
\hline 4 & $(8) 9.0 \pm 2.2$ & $(12) 9.3 \pm 1.2$ & $(8) 26.8 \pm 6.1$ & $(12) 28.0 \pm 3.3$ & $(8) 50.9 \pm 26.6$ & $(8) 26.3 \pm 22.4$ \\
\hline 5 & $(19) 6.6 \pm 0.7$ & $(19) 8.4 \pm 1.0$ & $(19) 20.7 \pm 2.9$ & $(19) 25.2 \pm 2.8$ & $(5) 79.6 \pm 5.0$ & $(5) 46.0 \pm 20.9$ \\
\hline 6 & $(3) 8.7 \pm 1.1$ & 10.2 & $(3) 30.6 \pm 4.8$ & 31.9 & 30.0 & 18.2 \\
\hline 7 & $(2) 9.6 \pm 0.2$ & $(2) 9.8 \pm 1.3$ & $(2) 27.6 \pm 0.1$ & $(2) 28.1 \pm 2.0$ & $(2) 55.5 \pm 0.7$ & $(2) 19.9 \pm 9.8$ \\
\hline 8 & 8.2 & 8.5 & 23.7 & 24.6 & 50.3 & N/A \\
\hline 9 & $(32) 5.3 \pm 0.9$ & $(31) 7.5 \pm 1.5$ & $(30) 15.9 \pm 3.2$ & $(32) 21.4 \pm 4.9$ & $(2) 61.3 \pm 25.9$ & $(7) 39.2 \pm 16.8$ \\
\hline 10 & 9.9 & 10.6 & 26.9 & 29.9 & 75.0 & 37.0 \\
\hline $\begin{array}{l}\text { Total } \\
\text { Average }\end{array}$ & $(166) 7.6 \pm 1.8$ & $(162) 9.1 \pm 1.5$ & $(161) 22.8 \pm 5.5$ & $(167) 26.8 \pm$ & $(101) 55 \pm 20.4$ & $(106) 25.5 \pm 16.1$ \\
\hline
\end{tabular}

$\mathrm{Hb}=$ Hemoglobin Hct $=$ Hematocrit N/A = Data not available PLT $=$ Platelet WBC $=$ white blood cell The pre- and post-exchange numbers that do not match are due to the fact that corresponding data could not be found.

$*$ (n) mean \pm Standard Deviation; the difference between the post-exchange and pre-exchange values for all parameters shown in the total average row are significant with $\mathrm{p}<0.001$.

Table III. Clinical Outcomes of Priapism after Red Blood Cell Exchange Transfusions

\begin{tabular}{|l|l|}
\hline Patient & Clinical Outcome \\
\hline 1 & Resolved but recurred every 6-8 months \\
\hline 2 & Resolved but recurred every 4-6 months \\
\hline 3 & Resolved, started on Hydroxyurea \\
\hline 4 & Resolved, started on Hydroxyurea \\
\hline 5 & Failed to respond, required surgery and penile implant, non-responder to Hydroxyurea \\
\hline 6 & Resolved \\
\hline 7 & Resolved \\
\hline 8 & Failed to respond, required surgery and penile implant \\
\hline 9 & Resolved \\
\hline 10 & Partial resolution, Genitofemoral neuralgia post-exchange, started on Hydroxyurea \\
\hline
\end{tabular}


Table IV. Reported Hematologic Values before and after Red Blood Cell Exchange Transfusion

\begin{tabular}{|l|l|l|l|}
\hline Parameter & Pre-exchange & Post-exchange & Reference \\
\hline Hemoglobin & $(1) 6.3$ & $(1) 13.5$ & Siegel et al. 1993 \\
\hline & $(6) 7.3 \pm 1,4$ & (6) $12.1 \pm 1.1$ & Rackoff et al. 1992 \\
\hline & $(166) 7.6 \pm 1.8$ & $(162) 9.1 \pm 1.5 *$ & This report \\
\hline Hematocrit & N/A & N/A & Siegel et al. 1993 \\
\hline & N/A & N/A & Rackoff et al. 1992 \\
\hline & $(161) 22.8 \pm 5.5$ & $(167) 26.8 \pm 4.8$ & This report \\
\hline
\end{tabular}

N/A: not available; $* \mathrm{p}<0.001$ compared to the values in the first two rows. 